\title{
Pengaruh metode pembelajaran musikal bagi kemampuan kognitif anak autis di SLB Negeri Manekat Niki-Niki
}

\author{
Erli Njudang $^{1^{*}}$, Yulius Yusak Ranimpi ${ }^{2}$, Iky Sumarthina P. Prayitno ${ }^{3}$ \\ ${ }^{1}$ Progam Studi Magister Sosiologi Agama, Fakultas Teologi, Universitas Kristen Satya Wacana. \\ Salatiga, Jawa Tengah, 50711, Indonesia. \\ *E-mail: erlinjudang@gmail.com, Telp: +6282314100514
}

\begin{abstract}
Abstrak: Kemampuan kognitif yang merupakan aspek penting bagi individu perlu dibekali dan dikembangkan sejak masa kanak-kanak. Namun, bagi anak dengan autisme, permasalahan pada kemampuan kognitif membuat mereka kesulitan dalam mengikuti proses pembelajaran di dalam kelas. Oleh karenanya, diperlukan suatu metode belajar baru yang diharapkan dapat membantu anak autis dalam mengembangkan kemampuan kognitif mereka demi mendukung aktivitas belajar. Penelitian ini bertujuan untuk mengetahui pengaruh metode pembelajaran musikal bagi kemampuan kognitif siswa autis. Subjek adalah 3 orang siswa autis yang kesuliatan menyusun bahasa dalam berkomunikasi, kesulitan berkonsentrasi, dan berperilaku repetitif di SLBN Manekat Niki-Niki. Metode penelitian yang digunakan adalah kuantitatif pre-experimental design dengan one group pretest-posttest design. Teknik analisis data yang digunakan adalah analisis statistik deskriptif. Hasil penelitian menunjukkan bahwa, metode pembelajaran musikal efektif dan berpengaruh bagi kemampuan kognitif siswa autis yang memiliki keterbatasan dalam berkonsentrasi dan berperilaku repetitif, namun belum cukup efektif bagi siswa autis yang memiliki gangguan perkembangan bahasa dalam berkomunikasi.
\end{abstract}

Kata Kunci: metode pembelajaran musikal, kognitif, autisme

\section{The impact of musical learning method on the cognitive ability of autistic children in SLB Negeri Manekat Niki-Niki}

\begin{abstract}
As well as children in general, the cognitive ability of children with autism needs to be developed. The cognitive disability in children with autism causes difficulty in their classroom learning activities. Therefore, there must be needed a new learning method to develop the cognitive ability of children with autism in their learning activities. This research aims to discover the impact of musical learning method on the cognitive abilities of autistic students. The subjects are 3 students with autism with difficulties in language and communication, concentrating, and behaving repetitively in SLBN Manekat Niki-Niki. This research method is pre-experimental design quantitative with one group pretest-posttest design. The data analysis technique is descriptive statistical analysis. The results show that musical learning method is an effective method to develop the cognitive abilities of autistic students with difficulty in concentrating and repetitive behavior, but not quite effective for autistic students with language and communication difficulty.
\end{abstract}

Keywords: musical learning method, cognitive, autism

\section{PENDAHULUAN}

Kemampuan kognitif merupakan salah satu aspek yang perlu dikembangkan oleh individu dalam rangka mengembangkan pengetahuannya tentang apa yang dilihat, didengar, diraba, dirasa, ataupun dicium melalui panca indera yang dimiliki (Sujiono dan Sujiono, 2008). Oleh karena itu, kemampuan kognitif perlu dibekali dan dikembangkan oleh individu sejak masa kanak-kanak, tidak terkecuali pada anak dengan autisme.

Berbeda dengan anak pada umumnya, kemampuan kognitif pada anak dengan autisme berkembang lebih lambat. Penelitian yang dilakukan oleh Long et al. (2011) menunjukkan bahwa nilai kemampuan kognitif, bahasa, reseptif, dan berekspresi anak dengan autisme lebih rendah daripada anak tanpa autisme, yang ditunjukkan dengan hasil sebagai berikut: rata-rata kemampuan kognitif anak dengan ASD lebih rendah yakni 82.2 dibandingkan kemampuan kognitif anak tanpa ASD yakni 90.1; rata-rata kemampuan kognitif anak dengan ASD berdasarkan umur lebih rendah yakni 20.9 
JPK (Jurnal Pendidikan Khusus), 16 (1), 2020 - 9

Erli Njudang, Yulius Yusak Ranimpi, Iky Sumarthina P. Prayitno

dibandingkan dengan anak tanpa ASD yakni 22.7; rata-rata kemampuan bahasa anak dengan ASD lebih rendah yakni 65.4 dibandingkan kemampuan bahasa anak tanpa ASD yakni 81.6; rata-rata kemampuan reseptif anak dengan ASD lebih rendah yakni 17.5 dibandingkan dengan anak tanpa ASD yakni 19.1, dan; rata-tara kemampuan ekspresi anak dengan ASD lebih rendah yakni 14.3 daripada anak tanpa ASD yakni 18.8. Pendapat yang sama dikemukakan oleh Sunartini dalam Nugraheni (2016) bahwa sebagian anak dengan autis menunjukkan fungsi intelektual di bawah rata-rata, 40\% IQ di bawah 50, 30\% IQ antara 50-70, 30\% IQ di atas 70. Hal serupa dikemukakan oleh Sihotang (2018) dalam tesisnya bahwa sebagian besar anak autis mempunyai rata-rata skor IQ 50 dan mengalami keterbelakangan mental. Lambatnya perkembangan kognitif menandakan adanya masalah pada kemampuan kognitif anak dengan autisme yang mengakibatkan mereka mengalami kesulitan dalam menerima serta memahami informasi dan materi pembelajaran dan informasi di kelas.

Hodgdon dalam Mutaqin (2016) mengatakan bahwa sebagian besar anak autis adalah pembelajar dengan visual. Oleh karena itu, tidak jarang para pengajar menggunakan media gambar dan bahasa tubuh dalam upaya pengembangan kognitif anak dengan autisme. Namun dalam pelaksanaannya, terlepas dari efektifitas penggunaan media tersebut yang dapat membantu anak dalam memahami suatu kejadian dan juga berkomunikasi, metode visual juga memiliki beberapa kekurangan. Mutaqin (2016) menunjukkan beberapa kendala dalam pelaksanaan strategi visual, yakni:

1. Kurangnya kontak mata anak ketika diperlihatkan gambar-gambar;

2. Kesulitan mengungkapkan pesan keterampilan dalam suatu objek gambar;

3. Adanya orang tua dan lingkungan yang kurang memahami kondisi anak;

4. Kesulitan mendapatkan gambar yang sesuai untuk mendukung strategi visual yang diberikan; dan

5. Penyampaian kalimat yang mendukung strategi visual yang diberikan.

Kekurangan yang ditemukan pada metode visual mengidentifikasikan bahwa pembelajaran anak dengan autisme tidak hanya membutuhkan satu metode saja. Widajati \& Alfinina (2013), dalam hasil penelitian tentang penggunaan media visual dalam pembelajaran anak autis, mereka menyimpulkan bahwa penggunaan media visual memang membantu perkembangan kognitif anak dengan autisme, tapi mereka juga mengakui bahwa media visual pun membutuhkan media pelengkap seperti media audio dan peralatan proyeksi untuk membantu merangsang kemampuan kognitif mereka. Dengan kata lain, penggunaan media visual masih belum komprehensif sebagai metode pembelajaran bagi anak autis. Oleh sebab itu, diperlukan suatu metode belajar baru yang dapat membantu anak autis dalam mengembangkan kemampuan kognitif mereka demi mendukung aktivitas belajar di kelas.

Metode pembelajaran yang digunakan dalam penelitian ini adalah metode pembelajaran musikal yang diterapkan dengan cara mendengarkan musik, bernyanyi, memainkan alat musik, dan bergerak mengikuti musik. Secara umum, musik mempunyai pengaruh pada kehidupan manusia mulai dari bayi hingga menjadi dewasa sehingga musik memiliki manfaat yang amat luas mencakup aspek mental, fisik, kognitif, emosi, dan sosial (Sheppard, 2007). Sejumlah riset menjelaskan bahwa musik memiliki manfaat yang amat besar bagi peningkatan kualitas hidup anak berkebutuhan khusus. Hasil penelitian Mareta dalam Milyartini (2010) menjelaskan bahwa kegiatan bernyanyi dapat membantu siswa tunagrahita ringan dalam mengingat kosakata, memahami kosakata, dan menguasai kosakata. Penelitian yang dilakukan oleh Asri (2013) menunjukkan hasil bahwa ada pengaruh musik terhadap kemampuan berbahasa pada anak autis di Taman Pelatihan Harapan Makassar. Berdasarkan penelitian Melyana dalam Milyartini (2010) tentang proses pembelajaran musik bagi anak down syndrome di "Taman Musik Dian Indonesia” (Jakarta), diperoleh temuan bahwa melalui aktivitas mendengarkan musik, bergerak mengikuti musik, dan memainkan alat musik, anak down syndrome mengalami peningkatan dalam beberapa hal yakni, anak yang semula tidak bisa diatur, selalu berlarian di ruang belajar, mulai berubah mau memperhatikan guru, dan bekerja sama dengan teman yang lain. Anak yang sering marah, menggigit, dan memukul berkembang menjadi lebih tenang dan mau diatur.

Penelitian lain dilakukan oleh Anisa dalam Milyartini (2010) yang meneliti peranan kegiatan bermain musik terhadap perkembangan sosial anak dengan autisme di lembaga Prananda-Bandung. Hasil penelitiannya menjelaskan proses perolehan kemampuan berkomunikasi anak. Musik mampu menstimulasi kemampuan berkomunikasi melalui bahasa tubuh yang ditransformasikan secara bertahap menjadi kemampuan berbahasa verbal. Selain itu musik juga mampu menjembatani anak melakukan interaksi imajinatif menuju pada interaksi sosial yang sesungguhnya. Ada pula penelitian yang dilakukan oleh Sholikah (2015) mengenai pengaruh terapi musik klasik terhadap perkembangan kognitif anak yang mengalami retardasi mental. Hasil penelitiannya menunjukkan bahwa ada 
J PK (J urnal Pendidikan Khusus), 16 (1), 2020 - 10

Erli Njudang, Yulius Yusak Ranimpi, Iky Sumarthina P. Prayitno

pengaruh terapi musik klasik terhadap perkembangan kognitif anak yang mengalami retardasi mental. Setengah dari anak retardasi mental perkembangan kognitifnya cukup sebanyak 13 anak (43,3\%), dan sebagian kecil mengalami perkembangan kognitif kurang sebanyak 6 anak (20\%). Sedangkan hasil pengujian statistik diperoleh hasil ada pengaruh terapi musik klasik terhadap perkembangan kognitif anak yang mengalami retardasi mental dengan nilai koefisien korelasi sebesar -3.162 dengan tingkat signifikansi 0,002 ( $\mathrm{p}<0.05)$.

Berdasarkan hasil penelitian-penelitian di atas, dapat dikatakan bahwa musik mempunyai pengaruh yang sangat besar dalam kehidupan seseorang karena musik mencakup indra penglihatan, pendengaran, dan perasaan untuk membantu merangsang kemampuan kognitif anak dengan autisme. Berdasar pada pemikiran tersebut, maka ditetapkan tujuan penelitian yaitu untuk mengetahui pengaruh metode pembelajaran musikal bagi kemampuan kognitif siswa autis di SLB Negeri Manekat NikiNiki.

\section{METODE}

\section{Jenis Penelitian}

Jenis penelitian ini adalah kuasi eksperimen dengan pendekatan kuantitatif. Desain penelitian yang digunakan adalah One Group Pretest-Posttest Design. Penelitian ini menggunakan rancangan melalui observasi yang dilakukan sebelum pemberian perlakuan $\left(\mathrm{O}_{1}\right)$ disebut observasi awal dan observasi sesudah pemberian perlakuan $\left(\mathrm{O}_{2}\right)$ disebut observasi akhir, dengan tujuan agar hasil perlakuan lebih akurat karena dapat membandingkan keadaan sebelum dan sesudah diberikan perlakuan (Sugiono, 2011). Desain penelitian tersebut digambarkan sebagai berikut:

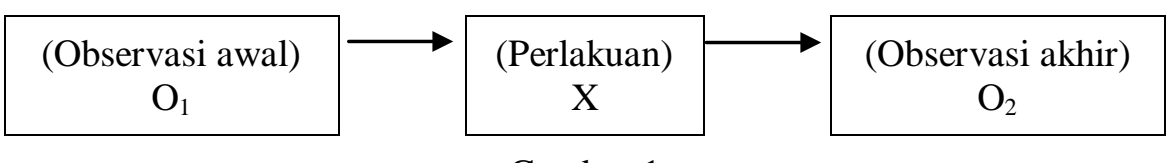

Gambar 1

Desain penelitian one group pretest-posttest design

\section{Tempat dan Waktu Penelitian}

Penelitian ini dilaksanakan di SLB Negeri Manekat Niki-Niki yang terletak di Jl. Timor Raya KM 135 Niki-Niki, RT 5/RW 2, Dusun Nekmese, Desa Bone, Kecamatan Amanuban Tengah, Kabupaten Timor Tengah Selatan, Provinsi Nusa Tenggara Timur. Pelaksanaan program penelitian adalah selama 16 pertemuan, terhitung tanggal 6 November sampai 27 November 2019.

\section{Subjek Penelitian}

Subjek dalam penelitian ini adalah 3 orang siswa autis di SLB Negeri Manekat Niki-Niki. Masing-masing berusia 9 dan 11 tahun di kelas 3 SD, dan seorang lainnya berusia 12 tahun di kelas 2 SMP.

\section{Instrumen Penelitian}

Dalam penelitian ini, peneliti menggunakan instrumen penelitian checklist pedoman observasi. Checklist dipilih peneliti karena checklist merupakan instrumen yang sesuai dengan metode observasi (Arikunto, 2010). Pedoman observasi kemampuan kognitif di bawah ini adalah modifikasi dari pedoman observasi kemampuan kognitif yang dirancang oleh Ratnasari (2017). 
J PK (J urnal Pendidikan Khusus), 16 (1), 2020 - 11

Erli Njudang, Yulius Yusak Ranimpi, Iky Sumarthina P. Prayitno

Tabel 1

Observasi Kemampuan Kognitif

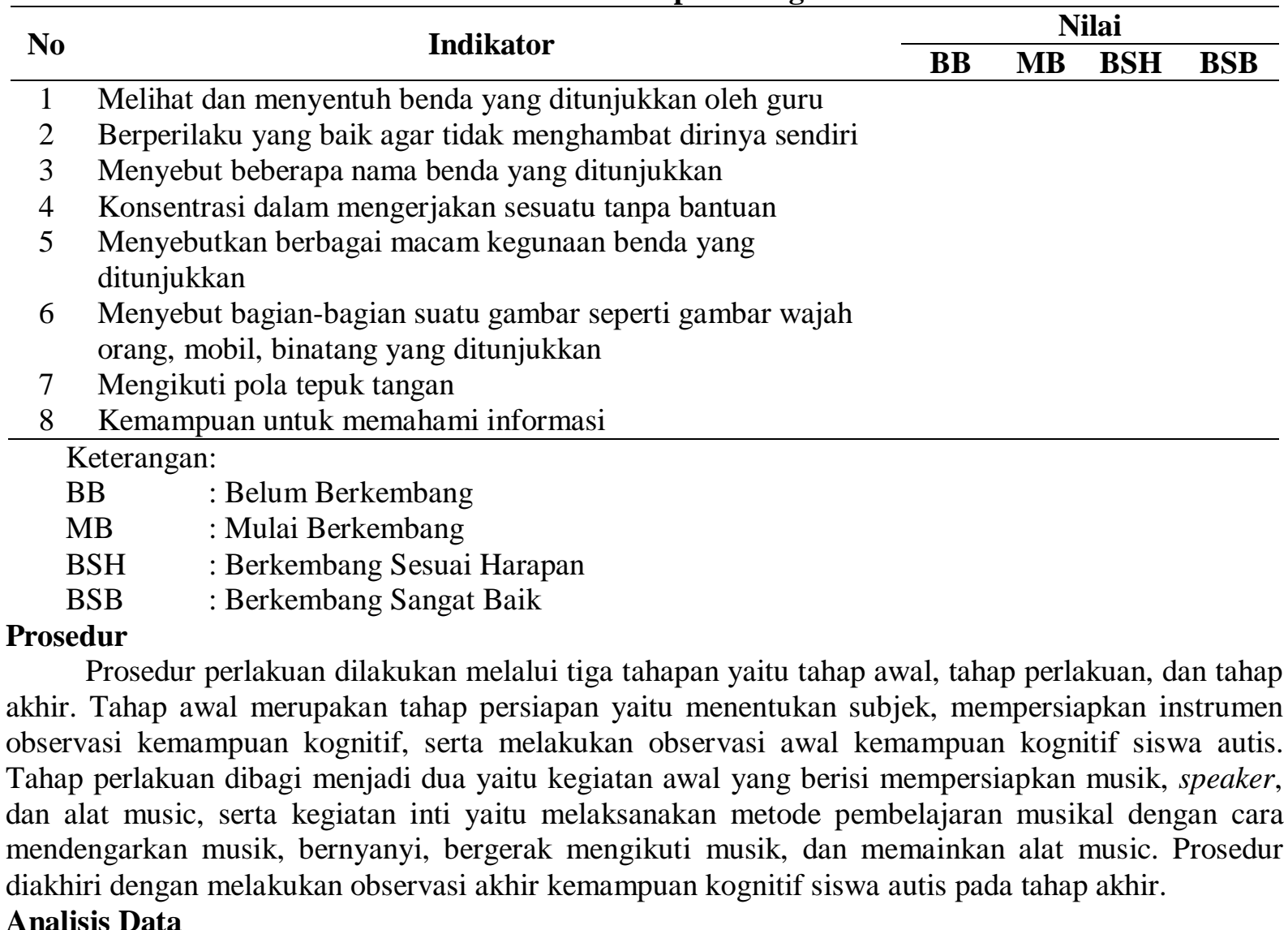

Analisis Data

Penelitian ini menggunakan teknik analisis data statistik deskriptif untuk menganalisis data yang telah terkumpul sebagaimana adanya tanpa bermaksud membuat kesimpulan yang berlaku untuk umum atau generalisasi. Secara teknis dapat diketahui bahwa, dalam statistik deskriptif tidak ada uji signifikansi, tidak ada taraf kesalahan (Sugiono, 2011).

\section{HASIL DAN PEMBAHASAN}

\section{Hasil}

Subjek dalam penelitian terdiri dari tiga siswa autism dengan inisial subjek IT, JGYA, dan AT. Adapun deskripsi ketiga subjek dalam penelitian ini adalah sebagai berikut:

1. Subjek IT

a. Kondisi awal kemampuan kognitif

IT adalah siswa autis di kelas 3 SD. Kemampuan kognitifnya mulai berkembang pada indikator melihat dan menyentuh benda yang ditunjukkan oleh guru dan pada indikator kemampuan untuk memahami informasi. Sementara itu, di lain sisi kemampuan kognitifnya belum berkembang pada indikator berperilaku yang baik agar tidak menghambat dirinya sendiri, menyebut beberapa nama benda yang ditunjukkan, konsentrasi dalam mengerjakan sesuatu tanpa bantuan, menyebut bagianbagian suatu gambar seperti gambar wajah orang, mobil, binatang yang ditunjukkan, dan mengikuti pola tepuk tangan.

Saat ini IT berumur 9 tahun namun mengalami keterlambatan perkembangan bahasa. IT tidak bisa berbicara dengan orang disekitarnya termasuk orang tuanya. Hal ini menyebabkan IT tidak mampu menyebutkan nama serta kegunaan dari suatu objek yang ditunjukkan kepadanya. Konsentrasi IT pun sangat terbatas, sehingga menyebabkan dia tidak mampu memahami informasi yang diberikan serta tidak mampu berkonsentrasi terhadap suatu pekerjaan. Kondisi ini sesuai dengan yang dikatakan oleh Aprianti (2016) bahwa salah satu ciri anak autis adalah mengalami keterlambatan perkembangan bahasa sehingga berpengaruh pada tingkat pemahaman anak yang tergolong dalam perkembangan kognitif. 
J PK (J urnal Pendidikan Khusus), 16 (1), 2020 - 12

Erli Njudang, Yulius Yusak Ranimpi, Iky Sumarthina P. Prayitno

\section{b. Kondisi akhir kemampuan kognitif}

Setelah metode musikal diterapkan dalam pembelajaran, maka terlihat perubahan berupa kemajuan dalam beberapa indikator. Kemampuan kognitif IT menunjukkan bahwa pada indikator melihat dan menyentuh benda yang ditunjukkan oleh guru terlihat berkembang sesuai harapan. Hal ini terlihat saat IT diarahkan untuk mengambil pensil IT mampu melakukannya meskipun dengan bantuan guru. Pada indikator berperilaku yang baik agar tidak menghambat dirinya sendiri terlihat mulai berkembang. Awalnya IT siswa yang suka mengompol di kelas, namun kebiasaan itu berubah secara perlahan. Ketika ingin buang air kecil, IT memberi isyarat kepada guru atau orang tuanya. Pada indikator mengikuti pola tepuk tangan terlihat mulai berkembang meskipun dengan bantuan guru. Indikator kemampuan untuk memahami informasi berkembang sesuai harapan. IT sudah mulai mengerti cara melepaskan dan menggunakan celana dengan benar saat buang air kecil tanpa bantuan guru maupun orang tua.

Terlepas dari beberapa perubahan kemampuan kognitif IT di atas yang menunjukkan adanya perubahan, di lain sisi ada juga beberapa indikator yang tidak mengalami perubahan sama sekali yakni, indikator menyebut beberapa nama benda yang ditunjukkan, menyebut berbagai macam kegunaan benda yang ditunjukkan, menyebut bagian-bagian suatu gambar seperti wajah orang, mobil, dan binatang yang ditunjukkan. Hal ini disebabkan karena IT mengalami keterlambatan dalam berbicara sehingga kegiatan 'menyebut' atau 'mengucapkan' belum berkembang secara baik. Pada indikator konsentrasi dalam mengerjakan sesuatu tanpa bantuan pun tidak mengalami perubahan. Dalam melaksanakan kegiatan belajar di kelas, IT masih belum bisa berkonsentrasi sendiri tanpa bantuan karena dengan bantuan pun, konsentrasi IT hanya bertahan kurang lebih 40 detik. Hal ini terlihat saat pelaksanaan Ujian Akhir Semester, IT dibantu gurunya memegang pensil untuk mewarnai, tetapi konsentrasi dan pandangan mata IT tidak tertuju pada buku gambarnya, melainkan pada buku dan pensil gambar milik teman yang duduk disebelahnya.

Berdasarkan data di atas, dapat dikatakan bahwa ada peningkatan terhadap kemampuan kognitif IT. Peningkatan ini menandakan bahwa penerapan metode musikal dalam belajar kepada anak IT memberikan pengaruh yang baik terhadap kemampuan kognitifnya meskipun peningkatan itu tidak terjadi secara menyeluruh. Menurut analisa penulis, hal utama yang mempengaruhi perkembangan IT sehingga tidak terjadi peningkatan secara menyeluruh terhadap aspek kognitifnya adalah karena hambatan dalam perkembangan bahasa. Namun, hal ini tidak menutup kemungkinan bahwa kemampuan berbahasa anak autis tidak bisa diatasi. Sumekar (2007) mengatakan bahwa anak autis tidak hanya enggan berbicara dan bukan hanya tidak mempunyai motivasi untuk berbicara akan tetapi lebih daripada itu. Hal ini diperkuat oleh sebagian besar peneliti yang mengatakan bahwa separuh anak autis tidak mampu menggunakan kemampuan berbahasanya. Ini berarti bahwa, anak autis bukan tidak bisa berbicara, melainkan mereka hanya tidak mampu menggunakan kemampuan berbahasanya.

\section{Subjek JGYA}

a. Kondisi awal kemampuan kognitif

JGYA adalah siswa autis di kelas 3 SD yang berumur 11 tahun. Kemampuan kognitifnya berkembang sangat baik pada indikator mengikuti pola tepuk tangan, sementara pada indikator berperilaku yang baik agar tidak menghambat dirinya sendiri, menyebut beberapa nama benda yang ditunjukkan, dan menyebut bagian-bagian suatu gambar seperti wajah orang, mobil, binatang yang ditunjukkan berkembang sesuai harapan. Kemampuan kognitif JGYA terlihat mulai berkembang pada indikator melihat dan menyentuh benda yang ditunjukkan oleh guru, menyebutkan berbagai macam kegunaan benda yang ditunjukkan, dan kemampuan untuk memahami informasi. Sementara pada indikator konsentrasi dalam mengerjakan sesuatu tanpa bantuan, kemampuan JGYA terlihat belum berkembang.

b. Kondisi akhir kemampuan kognitif

Setelah metode musikal diterapkan dalam pembelajaran, maka terlihat perubahan berupa kemajuan dalam semua indikator. Kemampuan kognitif JGYA menunjukkan bahwa pada indikator melihat dan menyentuh benda yang ditunjukkan oleh guru berkembang sangat baik. Hal ini ditunjukkan dalam kegiatan memainkan alat musik, ketika JGYA diminta untuk memainkan alat musik piano, dengan spontan JGYA memainkannya meskipun tidak sesuai dengan nada yang tepat. Pada indikator berperilaku yang baik agar tidak menghambat dirinya sendiri terlihat berkembang sangat baik. JGYA adalah siswa autis yang terkenal penurut. JGYA tidak melakukan hal-hal yang 


\section{J PK (J urnal Pendidikan Khusus), 16 (1), 2020 - 13}

Erli Njudang, Yulius Yusak Ranimpi, Iky Sumarthina P. Prayitno

membahayakan dirinya ataupun orang lain. Indikator menyebut beberapa nama benda yang ditunjukkan berkembang sangat baik. JGYA bisa menyebut dengan baik beberapa nama benda yang ditunjukkan seperti alkitab, tas, pensil, sepatu. Indikator konsentrasi dalam mengerjakan sesuatu tanpa bantuan berkembang sesuai harapan. Hal ini ditunjukkan saat mengikuti Ujian Akhir Semester, JGYA mampu mengerjakan soal dengan sangat baik, meskipun dengan sedikit bantuan dari guru. Indikator menyebutkan berbagai macam kegunaan benda yang ditunjukkan berkembang sesuai harapan. JGYA mampu menjelaskan fungsi beberapa benda yang ditunjukkan seperti, pensil untuk menulis, tas untuk menyimpan alat tulis, botol minum untuk mengisi air. Menyebutkan bagian-bagian suatu gambar seperti gambar wajah orang, mobil, binatang yang ditunjukkan. Hal ini ditunjukkan dengan kemampuan JGYA ketika menunjukkan kancing sebagai salah satu bagian dari baju, tali sebagai salah satu bagian dari sepatu, dan JGYA mampu menunjuk secara jelas bagian-bagian wajah seperti mata, telinga, hidung, mulut, pipi. Indikator mengikuti pola tepuk tangan berkembang sangat baik. Indikator kemampuan memahami informasi berkembang sangat baik. Hal ini ditunjukkan JGYA melalui kegiatan bernyanyi dan bermain musik. JGYA mampu memahami informasi berupa perintah dari guru atau peneliti.

Data tersebut menunjukkan bahwa ada peningkatan terhadap kemampuan kognitif JGYA yang menandakan bahwa penerapan metode musikal dalam belajar kepada JGYA, memberikan pengaruh yang baik terhadap kemampuan kognitifnya. Menurut analisa penulis, kegemaran akan bernyanyi menjadi salah satu indikator peningkatan tersebut. Ketika dalam belajar diterapkan metode musikal, kehadiran JGYA di sekolah semakin meningkat dan semakin bersemangat dalam mengikuti pembelajaran. JGYA semakin mudah diatur, sehingga bisa mengikuti setiap proses pembelajaran dengan baik. Hal ini sejalan dengan manfaat musik yang dikemukakan oleh DePorter (2001) bahwa musik dalam proses belajar dapat digunakan untuk meningkatkan semangat, merangsang pengalaman, menumbuhkan relaksasi, meningkatkan fokus, membina hubungan, memberi inspirasi, dan bersenangsenang.

\section{Subjek AT}

a. Kondisi awal kemampuan kognitif

AT adalah siswa autis di kelas 2 SMP yang berumur 12 tahun. Kemampuan kognitifnya berkembang sesuai harapan pada indikator melihat dan menyentuh benda yang ditunjukkan, berperilaku yang baik agar tidak menghambat dirinya sendiri, dan menyebut beberapa nama benda yang ditunjukkan. Hasil lain yaitu pada indikator konsentrasi dalam mengerjakan sesuatu tanpa bantuan, menyebutkan berbagai macam kegunaan benda yang ditunjukkan, menyebut bagian-bagian suatu gambar seperti gambar wajah orang, mobil, binatang yang ditunjukkan, mengikuti pola tepuk tangan, dan kemampuan untuk memahami informasi, kemampuan kognitifnya mulai berkembang.

b. Kondisi akhir kemampuan kognitif

Setelah metode musikal diterapkan dalam pembelajaran, terlihat perubahan yang sangat baik berupa kemajuan dalam semua indikator. Kemampuan kognitif AT menunjukkan bahwa pada indikator melihat dan menyentuh benda yang ditunjukkan oleh guru berkembang sangat baik. Hal ini ditunjukkan oleh perilaku AT saat diberi perintah untuk mengambil tas milik peneliti, AT mampu melakukannya. Pada indikator berperilaku yang baik agar tidak menghambat dirinya sendiri berkembangg sangat baik. AT tidak melakukan kegiatan atau aktivitas yang menghambat dirinya, sebaliknya dalam beraktivitas AT termasuk anak yang berhati-hati. Misalnya ketika kancing bajunya terlepas, AT cepat memungut dan memberitahu orang tuanya. Indikator menyebut beberapa nama benda yang ditunjukkan berkembang sangat baik.

Kemajuan yang baik juga terlihat dalam indikator konsentrasi dalam mengerjakan sesuatu tanpa bantuan yang berkembang sesuai harapan. Hal ini ditunjukkan AT saat bernyanyi solo di depan guru dan teman-temannya. Indikator menyebut berbagai macam kegunaan benda yang ditunjukkan berkembang sesuai harapan. Ketika ditanya apa fungsi dari sepatu yang AT pakai, AT menjawab agar kaki tidak kesakitan saat berjalan. Hasil baik lainnya juga ditunjukkan pada indikator menyebut bagian-bagian suatu gambar seperti gambar wajah orang, mobil, binatang yang ditunjukkan, indikator mengikuti pola tepuk tangan, indikator kemampuan untuk memahami informasi, telah berkembang sangat baik. Data di atas menunjukkan bahwa ada peningkatan terhadap kemampuan kognitif AT yang menandakan bahwa penerapan metode musikal dalam belajar ternyata memberikan pengaruh yang baik terhadap kemampuan kognitifnya. 


\title{
J PK (J urnal Pendidikan Khusus), 16 (1), 2020 - 14
}

\author{
Erli Njudang, Yulius Yusak Ranimpi, Iky Sumarthina P. Prayitno
}

Secara keseluruhan, hasil analisa terhadap data observasi di atas menunjukkan bahwa terdapat peningkatan yang baik terhadap kognitif IT, dan peningkatan yang sangat signifikan terhadap kognitif JGYA dan AT. Peningkatan kemampuan kognitif yang ditunjukkan oleh masing-masing subjek menandakan bahwa metode pembelajaran musikal yang diterapkan, efektif dan berpengaruh pada perkembangan kemampuan kognitif mereka.

\section{Pembahasan}

Autisme adalah gangguan perkembangan yang ditandai dengan adanya gangguan dan keterlambatan di bidang kognitif, bahasa, perilaku, komunikasi, dan interaksi sosial (Sintowati, 2007). Hasil asesmen terhadap ketiga subjek menunjukkan bahwa mereka miliki kesulitan menyusun bahasa dalam komunikasi, hambatan dalam berkonsentrasi, dan perilaku repetitif. Dalam berkomunikasi, anak autis mengalami kesulitan memproduksi bahasa dan memahami topik pembahasan yang di interaksikan melalui lingkungan sekitar. Mereka terkadang mengungkapkan kalimat yang terbalik, mengulang kalimat yang pernah didengar tetapi tidak sesuai dengan konteks. Selain itu, anak autis kurang menggunakan bahasa tubuh sehingga terkadang mereka lebih suka membeo, berteriak, dan menarik tangan seseorang untuk mengungkapkan apa yang diinginkan (Leki et al., 2019). Dampak bagi anak autis yang mengalami kesulitan berbicara dan berkomunikasi adalah sebagai berikut (Rahma et al., 2019):

1. Terlambat untuk memproduksi bicara, tanpa ekspresi dan gerak

2. Pengulangan kalimat yang diutarakan

3. Kalimat yang dikeluarkan tidak dapat dipahami oleh orang lain ataupun dirinya sendiri

4. Hanya bisa meniru kalimat yang diucapkan orang lain tanpa mengerti maksudnya atau pengertiannya

5. Menciptakan bahasa yang tidak dapat dimengerti orang lain

6. Jika anak penyandang autisme tidak berbicara maka ia akan menarik tangan orang lain untuk meminta sesuatu

Kesulitan-kesulitan di atas dialami oleh IT dan AT. Dalam kehidupan sehari-hari IT tidak mampu berbicara, IT hanya berteriak, membeo, atau menarik tangan orang lain untuk menyampaikan keinginannya. Misalnya, saat meminta minum IT berteriak sambil menunjuk ke arah botol minum. Sementara AT, seringkali mengulang kalimat yang sama meskipun tidak sesuai konteks pembicaraan. Kalimat yang AT perkatakan terkadang tidak dimengerti orang lain, AT hanya bisa meniru apa yang diucapkan orang tanpa mengerti maksud dari kalimat tersebut. Hal ini senada Prasetyono dalam Widiastuti (2014) yang mengatakan bahwa anak autis mengalami keterlambatan perkembangan bicara atau sama sekali tidak berkembang, tidak mampu memulai suatu pembicaraan atau memelihara suatu pembicaraan dua arah yang baik, bahasa tidak lazim yang diulang-ulang atau stereotip.

Selain mengalami kesulitan dalam berkomunikasi, anak autis juga memiliki keterbatasan dalam berkonsentrasi. Bektiningsih (2009) menjelaskan bahwa pada tahun 1970, peneliti di Swedia menemukan bahwa anak autis juga mengalami kesulitan dalam berkonsentrasi dan kesulitan dalam bertahan mengerjakan sesuatu atau tugas-tugas tertentu. Kesulitan ini dialami oleh anak IT, AT, dan JGYA yang ditunjukkan saat proses belajar. IT sangat sulit berkonsentrasi pada buku dan pensil miliknya sendiri, fokusnya pada pensil milik teman dan cenderung melakukan tindakan yang menyakiti orang lain. AT sulit berkonsentrasi ditunjukkan dengan perilaku suka menyendiri dengan tatapan kosong. Sementara itu, kesulitan JGYA dalam berkonsentrasi membuatnya susah mengingat bentuk huruf yang telah diajarkan.

Konsentrasi pada anak autism memiliki pengaruh yang besar terhadap proses pembelajaran. Jika anak autis kesulitan dalam berkonsentrasi, maka jelas terlihat kegiatan yang dilakukan akan sia-sia, apalagi saat berada di kelas. Anak akan dapat belajar dengan baik jika memiliki kemampuan konsentrasi yang baik, dengan kata lain anak penyandang autis harus memiliki kebiasaan untuk memfokuskan pikiran atau berkonsentrasi (Rokhimah \& Darmawanti, 2013).

Keterbatasan lain yang dialami subjek penelitian adalah perilaku repetitif. Hal ini tidak mengherankan terjadi pada anak autis sebab salah satu pengenalan tentang anak autis adalah perilaku repetitif. American Psychiatric Association (2013) melalui DSM-V, mengkategorikan perilaku repetitif anak autis dalam 4 gejala yakni:

1. Perkataan, gerak, dan penggunaan objek yang berulang-ulang

2. Rutinitas dan ritual yang diulang-ulang atau sulit menerima 
J PK (J urnal Pendidikan Khusus), 16 (1), 2020 - 15

Erli Njudang, Yulius Yusak Ranimpi, Iky Sumarthina P. Prayitno

3. Fokus dan minat yang berlebihan pada sesuatu

4. Masalah pada sensoris

Gejala-gejala di atas dialami oleh AT dan IT. AT selalu memperkatakan sebuah kalimat berulang-ulang yang tidak sesuai konteks dan tidak dapat dimengerti oleh lawan bicaranya. AT juga selalu berbicara dengan dirinya sendiri. Demikian juga IT yang selalu menunjukkan perilaku repetitif dengan menunjukkan minat yang berlebihan pada sesuatu. Misalnya, IT lebih mengagumi pensil milik teman daripada miliknya sendiri.

Keterbatasan-keterbatasan di atas, tentunya dapat menghambat proses pembelajaran yang berdampak pada lambatnya perkembangan kognitif sehingga diperlukan suatu metode pembelajaran yang dapat menarik minat dan perhatian siswa autis agar dapat belajar dengan baik. Oleh karena itu, dalam penelitian ini diterapkan suatu metode pembelajaran baru, yakni metode pembelajaran musikal. Metode ini diterapkan dengan mengajak subjek mendengarkan musik, bernyanyi, memainkan alat musik, dan bergerak mengikuti musik.

Dalam melaksanakan aktivitas mendengarkan musik IT, JGYA, dan AT sangat senang dan antusias. Terlihat dari perilaku mereka khususnya IT dan JGYA yang ingin mendengarkan musik setiap saat. Kebiasaan mendengarkan musik di sekolah ternyata mampu mengubah suasana hati dan mental siswa. JGYA yang terbiasa mendengarkan musik di rumah, dapat melatih mentalnya sehingga mampu menunjukkan kepercayaan diri untuk tampil di depan banyak orang. Sementara itu, IT yang juga dibiasakan oleh peneliti dalam mendengarkan musik, terlihat lebih tenang dan mudah diatur. Hal tersebut senada dengan DePorter (2001) yang mengatakan bahwa, aktivitas mendengarkan musik mampu menata suasana hati, mengubah keadaan mental siswa, dan mendukung lingkungan belajar. Di sisi lain, aktivitas mendengarkan musik memberi manfaat yang sangat signifikan bagi AT dalam berkonsentrasi dan mengingat. Adakalanya, banyak kata-kata baru atau nama-nama baru yang membuat AT kesulitan dalam mengingat. Namun, kegiatan mendengarkan musik yang dilaksanakan secara kontinu dapat mengatasi kesulitan yang dialaminya. Hal ini bisa dilihat pada kemajuan AT yang mampu mengingat nama peneliti dan menghafal lirik lagu. Penemuan ini sejalan dengan perkataan Campbell (2001) bahwa, mendengarkan musik sambil belajar dapat meningkatkan kemampuan seseorang untuk mengingat ejaan, puisi, dan kata-kata asing, juga senada dengan Djohan (2016) yang mengatakan bahwa, mendengarkan musik dapat mengembangkan keterampilan kognisi, seperti memori dan konsentrasi.

Di samping itu, aktivitas bernyanyi memberi kesempatan kepada anak untuk menggunakan suara mereka sebagai alat musik, sehingga secara tidak langsung bernyanyi dapat melatih kepekaan musikalitas pada anak tersebut (Busroh, 1988). Selain itu, bernyanyi juga dapat membantu anak yang mengalami gangguan perkembangan artikulasi dan keterampilan bahasa, irama, dan kontrol pernapasan (Djohan, 2016). Pendapat ini sejalan dengan hasil penelitian terhadap AT dan JGYA yang mampu bernyanyi dengan artikulasi, irama, dan kontrol pernapasan yang tepat dan baik. Kemampuan mereka dibuktikan dengan kebiasaan tampil bernyanyi di depan umum. Kemampuan ini sekaligus membuktikan bahwa kegiatan bernyanyi yang dilakukan secara kontinu dapat melatih mereka dalam mengingat dan menguasai kosakata baru. Hasil penelitian ini sejalan dengan hasil penelitian dari Mareta dalam Milyartini (2010) yang menjelaskan bahwa, kegiatan bernyanyi dapat membantu siswa tunagrahita ringan dalam mengingat, memahami, dan menguasai kosakata. Namun, perkembangan yang diharapkan tersebut tidak terjadi pada IT karena mengalami keterlambatan bahasa dan komunikasi.

Aktivitas memainkan alat musik, dapat membantu pengembangan dan koordinasi kemampuan motorik (Djohan, 2016). Dalam aktivitas ini, alat musik yang digunakan adalah piano. Ketiga subjek terlihat sangat antusias dan mempunyai keinginan serta ketertarikan terhadap alat musik piano. Dalam kegiatan ini, IT dan AT merasa lebih nyaman dan tenang, ditunjukkan dengan perilaku mereka yang ingin dipangku, dituntun tangan dan jarinya untuk bermain bersama. IT yang sebelumnya tidak tenang di kelas, suka mengganggu aktivitas temannya bahkan menyakiti dirinya sendiri, mulai lebih terkendali dan mudah diatur. Peningkatan yang lebih signifikan ditunjukkan oleh JGYA, ia mampu menirukan atau mengulang kembali cara bermain alat musik yang peneliti tunjukkan. Hal ini sejalan dengan hasil penelitian Wieminaty (2012) yang menunjukkan bahwa, aktivitas bermain musik klasik dapat berpengaruh terhadap peningkatan prestasi belajar siswa. Hasil penelitian menunjukkan kenaikan dari nilai uji T secara statistik dari nilai 83,87 menjadi 85,74. Hal ini disebabkan karena 
J PK (J urnal Pendidikan Khusus), 16 (1), 2020 - 16

Erli Njudang, Yulius Yusak Ranimpi, Iky Sumarthina P. Prayitno

musik klasik mengandung komposisi nada yang memberikan ketenangan, kenyamanan, dan ketentraman dalam konsentrasi belajar.

Hasil penelitian yang dilakukan oleh Romadhon (2012) tentang pembelajaran musik karawitan pada anak autis, menunjukkan bahwa pembelajaran musik karawitan dengan metode demonstrasi sangat efektif untuk membantu meningkatkan kemampuan kognitif anak dalam meniru dan mengingat cara memainkan alat musik. Selain itu, berdasarkan data penelitian yang diperoleh, aktivitas memainkan alat musik ternyata mampu menyentuh aspek perkembangan sosial ketiga subjek dengan guru, peneliti, dan teman-teman mereka. Hal ini terlihat dari perilaku IT, JGYA, dan AT yang memainkan alat musik secara bergantian dengan teratur, mereka juga saling berkomunikasi meskipun hanya sesaat melalui bahasa tubuh. Perkembangan yang sangat baik ditunjukkan oleh IT yang sebelumnya hanya bersosialisasi dengan bapak guru, sudah mampu bersosialisasi dengan teman lain, juga peneliti dan ibu guru. Hal ini sejalan dengan penelitian Anisa dalam Milyartini (2010) yang meneliti peranan kegiatan bermain musik terhadap perkembangan sosial anak dengan autisme di lembaga Prananda-Bandung. Hasil penelitiannya menjelaskan bahwa musik mampu menstimulasi kemampuan berkomunikasi melalui bahasa tubuh yang ditransformasikan secara bertahap menjadi kemampuan berbahasa verbal. Selain itu, musik juga mampu menjembatani anak melakukan interaksi imajinatif menuju pada interaksi sosial yang sesungguhnya.

Aktivitas bergerak mengikuti musik dapat membantu mengembangkan jangkauan fisiologis, menggabungkan mobilitas/ketangkasan/kekuatan, keseimbangan, koordinasi, konsistensi, pola-pola pernapasan, dan relaksasi otot (Djohan, 2009). Hal ini sejalan dengan hasil observasi terhadap IT, AT, dan JGYA pada indikator mengikuti pola tepuk tangan yang meningkat. Dapat dilihat pada data observasi kemampuan kognitif masing-masing subjek.

\section{Keterbatasan dalam Penelitian}

Melalui penelitian ini, ditemukan fakta bahwa ternyata metode pembelajaran musikal yang diterapkan, tidak sepenuhnya membantu dalam perkembangan bahasa dan komunikasi siswa autis. Hal ini bisa dilihat dari data observasi kemampuan kognitif IT yang tidak terjadi perubahan dalam indikator 'menyebut' atau 'mengucapkan'. Fakta lain yang ditemukan dalam penelitian ini adalah adaptasi siswa autis terhadap metode pembelajaran musikal membutuhkan waktu yang lebih panjang dibandingkan dengan siswa normal pada umumnya. Terbukti dari pelaksanaan metode pembelajaran musikal, yakni pada lima hari di awal penelitian terdapat kendala perilaku siswa autis yang sebagian besar menunjukkan keengganan menemui peneliti dan melakukan aktivitas musikal. Pada pertemuanpertemuan selanjutnya, subjek justru datang sendiri, akrab dengan peneliti, dan mau melakukan aktivitas musikal yakni mendengarkan musik, bernyanyi, memainkan alat musik, dan bergerak mengikuti musik bersama peneliti.

Penelitian ini juga menemukan fakta bahwa, suasana hati (mood) dan kemampuan dasar siswa menjadi salah satu tingkat keberhasilan proses belajar dengan menggunakan metode pembelajaran musikal. Dalam pelaksanaannya, suasana hati dan kemampuan siswa autis berbeda satu sama lain, sehingga subjek memiliki perbedaan kualitas dalam hal bernyanyi, memainkan alat musik, mendengarkan musik, dan bergerak mengikuti musik. Oleh sebab itu, peneliti bersama guru pendamping meminimalisir keadaan ini dengan metode individualized education programme (IEP), yaitu diterapkan secara individu dengan dilengkapi data observasi lengkap. Keterbatasan lain dalam penelitian ini adalah dalam hal desainnya dimana tidak menggunakan data terkuantitfikasi atau data angka sehingga tidak bisa dilakukan uji efektivitas menggunakan baik statistik parametrik maupun non parametrik.

\section{SIMPULAN}

Berdasarkan hasil penelitian dan pembahasan yang telah dilakukan, maka dapat disimpulkan bahwa subjek memiliki kesulitan menyusun bahasa dalam berkomunikasi, hambatan dalam berkonsentrasi, dan perilaku repetitif. Metode pembelajaran musikal efektif dan berpengaruh bagi kemampuan kognitif siswa dengan autis yang memiliki keterbatasan dalam berkonsentrasi dan berperilaku repetitif. Hal ini ditandai dengan berkembangnya indikator-indikator kemampuan kognitif antara lain, melihat dan menyentuh benda yang ditunjukkan oleh guru; berperilaku yang baik agar tidak menghambat dirinya sendiri; menyebut beberapa nama benda yang ditunjukkan; konsentrasi dalam mengerjakan sesuatu tanpa bantuan; menyebutkan berbagai macam kegunaan benda yang 
ditunjukkan; menyebut bagian-bagian suatu gambar seperti gambar wajah orang, mobil, binatang yang ditunjukkan; mengikuti pola tepuk tangan; dan kemampuan untuk memahami informasi. Selain itu, dalam pelaksanaan metode pembelajaran musikal, siswa dengan autis menunjukkan respon yang baik ditandai dengan sikap antusias dan bersemangat dalam mengikuti kegiatan mendengarkan musik, bernyanyi, memainkan alat musik, dan bergerak mengikuti musik.

Penelitian ini memiliki keterbatasan dimana metode pembelajaran musikal tidak begitu efektif pada siswa dengan autis yang memiliki gangguan perkembangan bahasa dan komunikasi, karena tidak berkembang dalam indikator menyebut, mengucapkan, dan bernyanyi. Selain itu juga terdapat keterbatasan dalam pelaksanan penelitian yakni masa adaptasi siswa autis yang membutuhkan waktu lama serta suasana hati (mood) dan kemampuan dasar mereka yang menjadi salah satu tingkat keberhasilan penelitian ini. Berdasar pada keterbatasan tersebut, maka peneliti lain yang tertarik pada masalah kognitif siswa autis dan hubungannya dengan metode pembelajaran musikal, peneliti menyarankan untuk mempertimbangkan kemampuan adaptasi siswa autis sehingga dapat melakukan pendekatan dengan waktu yang lebih lama. Selain itu, pelaksanaan metode musikal hendaknya dilakukan lebih santai mengikuti suasana hati dan kemampuan siswa autis secara individu. Peneliti berharap kekurangan terkait desain penelitian yang ada dalam penelitan ini dapat dilihat sebagai hal yang perlu dilengkapi dalam penelitian-penelitian selanjutnya.

\section{DAFTAR PUSTAKA}

American Psychiatric Association. (2013). Diagnostic and Statistical Manual of Mental Disorders (DSM-5). United States: American Psychiatric Association.

Aprianti, E. (2016). Media Lingkungan Alam Terhadap Kognitif Anak Autis. Jurnal Pendidikan Khusus, 7(4), 2-5.

Arikunto, S. (2010). Prosedur Penelitian Pendidikan Suatu Pendekatan Praktik. Jakarta: Rineka Cipta.

Asri, M. (2013). Pengaruh Pemberian Terapi Musik Klasik terhadap Kemampuan Berbahasa pada Anak Autis di Taman Pelatihan Harapan Makassar. Skripsi.

Bektiningsih, K. (2009). Program Terapi Anak Autis Di SLB Negeri Semarang. Jurnal Kependidikan, 39(2), 95-110.

Busroh, J. (1988). Pengajaran Musik Melalui Pengalaman Musik. Bandung: Proyek Pengembangan Lembaga Pendidikan Tenaga Kependidikan.

Campbell, D. G. (2001). Efek Mozart. Jakarta: Gramedia Pustaka Utama.

DePorter, B. (2001). Quantum Teaching, Mempraktekkan Quantum Learning di Ruang-ruang Kelas. Bandung: PT Nizan Pustaka.

Djohan. (2016). Psikologi Musik. Yogyakarta: Percetakan Galang Press.

Leki, D. R., Tat, F., \& Barimbing, M. (2019). Pengaruh Peran Orang Tua pada Terapi Wicara Terhadap Kemampuan Bicara pada Anak Penderita Autis di SDK STA. Maria Assumpta dan Pusat Layanan Autis Naimata Kota Kupang. CHM-K Applied Scientific Journal, 2(1), 44-56.

Long, C., Gurka, M. J., \& Blackman, J. (2011). Cognitive Skills of Young Children with and without Autism Spectrum Disorder Using the BSID-III. Autism Research and Treatment, 1-7.

Milyartini, R. (2010). Peran Musik bagi Anak Berkebutuhan Khusus: Diffable-Different Abilities. ResearchGate: Article.

Mutaqin, W. R. (2016). Keefektifan Strategi Visual dalam Pembelajaran Keterampilan Sosial pada Anak dengan KONDISI Spektrum Autis Tipe Sindroma Asperger (ASD). Jurnal Keterapian Fisik, 1(2), 147-152.

Nugraheni, S. A. (2016). Menguak Belantara Autisme. Buletin Psikologi, 20(1-2), 9-17.

Rahma, D., Oktaviasari, F., \& Malang. (2019). Analisis Cara Berbahasa Anak Penyandang Autisme. Prosiding SENASBASA, 3(2), 200-208. 
J PK (J urnal Pendidikan Khusus), 16 (1), 2020 - 18

Erli Njudang, Yulius Yusak Ranimpi, Iky Sumarthina P. Prayitno

Ratnasari, L. D. (2017). Upaya Meningkatkan Kemampuan Kognitif Anak Autis Melalui Strategi Pembelajaran Musik di Sekolah Khusus Autis Bina Anggita Gedongkuning Yogyakarta Tahun Ajaran 2016-2017. Skrip.

Rokhimah, R., \& Darmawanti, I. (2013). Pengaruh Permainan Lasy Terhadap Peningkatan Konsentrasi pada Anak Autis. Jurnal Psikologi Teori Dan Terapan, 4(1), 48-55.

Romadhon, T. (2012). Pembelajaran Musik Karawitan Pada Anak Autis Di SLB Bina Anggita Yogyakarta. Skripsi.

Sheppard, P. (2007). Music Makes Your Child Smarter: Peran Musik dalam Perkembangan Anak. Jakarta: Gramedia Pustaka Utama.

Sholikah, H. S. (2015). Pengaruh Terapi Musik Klasik Terhadap Perkembangan Kognitif Anak yang Mengalami Retardasi Mental di SDLB Negeri Banjar Mendalan, Lamongan. Surya: Jurnal Media Komunikasi Ilmu Kesehatan, 07(01), 38-45.

Sihotang, C. P. (2018). Peran Komunikasi Interpersonal Guru dengan Siswa Autis dalam Mengembangkan Kecakapan Sosial di SLB Citra Mulia Matri Selomartani Sleman Yogyakarta. Tesis.

Sintowati, R. (2007). Autisme. Jakarta: Sunda Kelapa Pustaka.

Sugiono. (2011). Metode Penelitian Pendidikan (Pendekatan Kuantitatif, Kualitatif, dan R\&D). Bandung: Alfabeta.

Sujiono, Y. N., \& Sujiono, B. (2008). Metode Perkembangan Kognitif. Jakarta: Universitas Terbuka.

Sumekar, I. (2007). Pengaruh Terapi Musik Klasik Terhadap Kemampuan Berbahasa pada Anak Autis di Pusat Terapi Terpadu A Plus Jalan Imam Bonjol Batu. Skripsi.

Widajati, W., \& Alfinina, B. (2013). Penggunaan Media Visual dalam Pembelajaran Anak Autis. Pendidikan Luar Biasa, 9(1), 26-34.

Widiastuti, D. (2014). Perilaku Anak Berkebutuhan Khusus Gangguan Autisme di SLB Negeri Semarang Tahun 2014. BELIA: Early Childhood Education Papers, 3(2), 72-78.

Wieminaty, A. F. (2012). Pengaruh Belajar Musik Klasik Terhadap Peningkatan Prestasi Belajar pada Anak Sekolah Dasar di Studio Musik Purwacaraka Surakarta. Karya Tulis Ilmiah.

\section{PROFIL SINGKAT}

Erli Njudang yang merupakan penulis pertama lahir di tahun 1996 dan saat ini merupakan mahasiswa aktif di Program Studi Magister Sosiologi Agama, Fakultas Teologi, Universitas Kristen Satya Wacana. Pada tahun 2017 telah menyelesaikan pendidikan S1 Teologi (S.si, Teol) di Fakultas Teologi, Universitas Kristen Satya Wacana, Salatiga. Penulis kedua yaitu Yulius Y. Ranimpi, lahir di tahun 1973. Yulius merupakan dosen di Fakultas Teologi Universitas Kristen Satya Wacana. Latar belakang pendidikannya pada jenjang strata 1 adalah Psikologi (S.Psi, 1997) dan untuk strata 2 adalah Sosiologi Agama (M.Si, 2002). Gelar doktoralnya (PhD, 2017) diraih di University of the Sunshine Coast, Queensland-Australia di bidang Indigenous Health. Penulis ketiga Iky Sumarthina P. Prayitno, Th.D lahir di Kupang 10 Juli 1984. Mengenyam pendidikan S1 Teologi UKSW, S2 Sosiologi Agama UKSW, S2 Teologi PCTS Korea Selatan dan S3 Pendidikan Agama Kristen PCTS Korea Selatan. Saat ini mengampu matakuliah-mata kuliah Teologi Praktika di UKSW. 